\title{
Pengaruh Aplikasi Gliserin pada Kekerasan Resin Komposit Nanofiller dengan Perendaman Cuka Apel
}

\section{(Effect of Glycerin Application on Hardness of Nanofiller Composite with Immersion of Apple Cider Vinegar)}

\author{
Putri Nila Kharisma, Raditya Nugroho, Roedy Budirahardjo \\ Fakultas Kedokteran Gigi Universitas Jember \\ Jl. Kalimantan 37, Jember 68121 \\ e-mail korespondensi: putrikharisma26@gmail.com
}

\begin{abstract}
Composite resin is a type of filling material that is often used because it has good bonds with dentine and enamel and has a high aesthetic value. Nanofiller composite resin has high hardness, good polishing, color accuracy, and good translucency. The hardness of composite resins can change caused by low $\mathrm{pH}$ beverage. To determine the differences in effect of glycerin application on hardness of nanofiller composite resins with immersion of apple cider vinegar. The type of research used was experimental laboratories with a pretest and post test group design. Samples were 24 immersion in apple vinegar for 60 and 120 minutes. Measurement of hardness using the Vicker Hardness Tester to determine the hardness value. Data analysis was performed using One Way Anova and Post-Hoc LSD tests. There is a significant difference in the value of composite resin hardness in the entire study group. The highest hardness value was found in the group with the application of glycerin and without immersion, while the lowest value was found in the group without the application of glycerin and immersion in 120 minutes.
\end{abstract}

Keywords: nanofiller composite resin, hardness, glycerin, apple cider vinegar

\begin{abstract}
Abstrak
Resin komposit merupakan jenis bahan tumpatan yang sering digunakan karena memiliki ikatan yang baik dengan dentin dan enamel serta memiliki nilai estetis yang tinggi. Resin Komposit nanofiller memiliki kekerasan tinggi, polishing yang baik, ketepatan warna, dan translusensi baik. Resin komposit dapat mengalami perubahan kekerasan salah satunya disebabkan oleh minuman dengan $\mathrm{pH}$ rendah. untuk mengetahui perbedaan pengaruh aplikasi gliserin terhadap kekerasan resin Komposit nanofiller dengan perendaman cuka apel. Jenis penelitian yang digunakan adalah eksperimental laboratories dengan rancangan penelitian post test only control group design. Sampel berjumlah 24 direndam dalam cuka apel selama 60 dan 120 menit. Pengukuran perubahan kekerasan menggunakan Vicker Hardness Tester untuk mengetahui nilai kekerasannya. Analisis data dilakukan menggunakan uji One Way Anova dan Post-Hoc LSD. Terdapat perbedaan nilai kekerasan resin komposit yang signifikan pada seluruh kelompok penelitian. Nilai kekerasan tertinggi terdapat pada kelompok dengan aplikasi gliserin dan tanpa perendaman, sedangkan nilai terendah terdapat pada kelompok tanpa aplikasi gliserin dan perendaman 120 menit.
\end{abstract}




\section{Pendahuluan}

Resin komposit merupakan struktur yang tersusun dari tiga komponen utama yaitu polimer yang berikatan silang dengan baik dan diperkuat oleh dispersi kaca, mineral atau partikel filler resin dan coupling agent [1]. Resin komposit dapat diklasifikasikan berdasarkan pada beberapa hal, yaitu berdasarkan ukuran rata-rata partikel bahan pengisi, berdasarkan sistem aktivator-inisiator, berdasarkan karakter manipulasinya [2] dan komponen matriksnya [3]. Klasifikasi berdasarkan ukuran rata-rata bahan pengsi, resin komposit telah mengalami perkembangan dari macrofiller menjadi microfiller dan dari hybrida ke microhybrid [4]. Pada perkembangan terakhir, munculah resin komposit dengan ukuran partikel filler yang lebih kecil dan sistem ikatan yang lebih baik, yaitu resin komposit nanofiller. Resin ini memiliki ukuran partikel 0,1-100 nm [5].

Komposit nano memiliki keunggulan sendiri seperti kontraksi rendah selama tahap polimerisasi, tinggi dalam karakteristik mekanik dan estetik, stabilitas warna yang baik dan retensi yang baik setelah pemolesan [6]. Resin komposit dalam pengaplikasiannya dilapisi dengan gliserin sebelum dilakukan curing. Gliserin merupakan hasil produksi dari biodiesel dalam bentuk cair. Pemberian gliserin dilakukan untuk mengurangi lapisan Oxygen Inhibition Layer (OIL). Lapisan OIL dapat menurunkan kekerasan permukaan, wear resistance, dan adaptasi marginal resin komposit [7].

Resin komposit memilki berbagai sifat mekanis, diantaranya yaitu kekerasan. Kekerasan merupakan energi yang dibutuhkan untuk menekan material ke titik fraktur. Kekerasan didalam kedokteran gigi juga digunakan untuk mengetahui kemampuan bahan tumpatan dalam menahan daya tekan pengunyahan [8]. Sifat kekerasan resin komposit dapat dipengaruhi oleh beberapa faktor, diantaranya yaitu sifat fisik yang meliputi penyerapan air dan kelarutan, sifat kimiawi yang meliputi lama penyinaran, jarak penyinaran, ketebalan resin komposit dan polimerisasi bahan. Faktor lainnya yaitu minuman dan makanan yang dikonsumsi pasien. Makanan dan minuman yang mengandung asam dapat mempengaruhi resin komposit karena dapat mendegradasi matriks sehingga kekerasan resin mengalami penurunan. Degradasi matriks merupakan terputusnya gugus metakrilat pada Bis-GMA karena polimer resin komposit mengandung ikatan yang tidak stabil, sehingga dapat terdegradasi dengan mudah jika terpapar oleh $\mathrm{pH}$ yang rendah (asam) [9].

Minuman asam yang sering dikonsumsi diantaranya adalah cuka apel. Cuka apel adalah cairan fermentasi buah apel yang difermentasikan oleh khamir dan bakteri acetobacter aceti [10]. Senyawa organik dapat dikatakan asam jika memiliki $\mathrm{pH}$ rendah yaitu kurang dari $7(\mathrm{pH}<7)$. Cuka apel merupakan salah satu minuman dengan $\mathrm{pH}$ rendah, sehingga memiliki sifat asam. $\mathrm{pH}$ cuka apel berkisar di antara 2-3,5 tergantung pada konsentrasi asam asetat di dalamnya[11].

Kekerasan resin komposit dapat diukur mengggunakan beberapa uji kekerasan yang dapat dibagi menjadi tiga metode yaitu metode gores, metode pantul, dan metode indentasi [12]. Kedokteran gigi memiliki berbagai uji kekerasan yang sering digunakan, diantaranya yaitu brinell hardness test, knopp hardness test, Rockwell hardness test, dan vicker hardness test. Uji brinell dan rockwell merupakan uji kekerasan makro, sedangkan uji vicker dan knoop merupakan uji kekerasan mikro. Uji kekerasan dengan metode vicker bertujuan untuk menentukan kekerasan suatu material yaitu daya tahan material terhadap indentor intan yang cukup kecil dan mempunyai bentuk geometri berbentuk piramida. Alat yang digunakan dalam penelitian ini adalah alat uji kekerasan vickers hardness tester. Nilai keras mikro vickers adalah hasil bagi antara beban tekan statis maksimum dengan luas bidang penetrator [13].

\section{Metode Penelitian}

Jenis penelitian ini adalah eksperimental laboratories, dengan rancangan penelitian post test only control group design. Penelitian ini dilaksanakan di Laboratorium Metalurgi Fakultas Teknik Industri Institut Teknologi Sepuluh Nopember Surabaya, Klinik Konservasi Rumah Sakit Gigi dan Mulut Fakultas Kedokteran Gigi Universitas Jember, Laboratorium Kedokteran Gigi Terpadu Fakultas Kedokteran Gigi Universitas Jember dan Laboratorium Biomedik Fakultas Kedokteran Gigi Universitas Jember pada bulan Agustus - Oktober 2018. Variabel penelitian ini adalah perubahan kekerasan resin komposit nanofiller dengan aplikai gliserin setelah perendaman dalam cuka apel. Kriteria sampel yakni lempeng resin komposit berbentuk tabung dengan diameter $5 \mathrm{~mm}$ dan tinggi $2 \mathrm{~mm}$ dengan permukaan datar, licin, padat, halus dan tidak kasar. Sampel pada penelitian ini dibagi 
menjadi 6 kelompok $(n=4)$ sesuai lama perendaman pengaplikasian gliserin, yaitu dengan gliserin tanpa perendaman, tanpa gliserin tanpa perendaman, dengan gliserin dan perendaman 60 menit, dengan gliserin dan perendaman 120 menit, dengan gliserin dan perendaman 60 menit, dengan gliserin dan perendaman 120 menit. Alat yang digunakan untuk menguji perubahan warna yaitu Vicker Hardness Tester.

Prosedur penelitian dimulai dari pembuatan sampel dengan aplikasi gliserin dan tanpa gliserin. Prosedur kedua membuat larutan perendaman dengan melarutkan $30 \mathrm{ml}$ cuka apel dalam $236 \mathrm{ml}$ air. Prosedur ketiga yaitu dilakukan perendaman sampel gliserin dan tanpa gliserin dalam larutan cuka apel selama 60 menit dan 120 menit. Sampel yang telah direndam selanjutnya diukur nilai kekerasan menggunakan vicker hardness tester.

Data yang sudah ditabulasi kemudian diuji distribusi normalitasnya menggunakan uji Shapiro-Wilk dan uji homogenitas varian dengan uji Levene. Hasil yang didapatkan data berdistribusi normal dan homogen, maka dilanjutkan dengan uji parametrik One Way Anova. Hasil dari uji One Way Anova yaitu terdapat perbedaan, maka dilanjutkan dengan uji Post-Hoc LSD (Least Significance Different).

\section{Hasil Penelitian}

Hasil yang diperoleh dari penelitian yang telah dilakukan adalah sebagai berikut:

Tabel 1. Hasil uji kekerasan resin komposit nanofiller setelah dilakukan perendaman dalam larutan cuka apel (VHN)

\begin{tabular}{ccccccc}
\hline Kelompok & 1 & 2 & 3 & 4 & 5 & 6 \\
\hline Sampel 1 & 101,90 & 90,43 & 81,80 & 66,80 & 70,86 & 53,60 \\
Sampel 2 & 96,13 & 91,16 & 76,10 & 63,26 & 69,90 & 55,90 \\
Sampel 3 & 97,26 & 86,60 & 75,23 & 65,03 & 71,00 & 46,96 \\
Sampel 4 & 92,36 & 88,13 & 83,06 & 67,70 & 73,56 & 56,00 \\
\hline $\bar{x}$ & 96,91 & 89,08 & 79,04 & 69,53 & 69,42 & 57,36
\end{tabular}

Tabel 1 menunjukkan bahwa nilai uji kekerasan resin komposit yang menggunakan gliserin lebih tinggi dan resin komposit yang dilakukan perendaman dalam cuka apel memiliki nilai kekerasan yang lebih rendah. Lama perendaman 60 menit dan 120 menit menunjukkan bahwa selisih yang paling besar adalah pada pada kelompok perlakuan perendaman 120 menit. Selisih rata-rata nilai uji kekerasan setelelah perendaman paling rendah adalah pada kelompok perlakuan 60 menit.

e-Journal Pustaka Kesehatan, vol.8 (no.2), Mei 2020

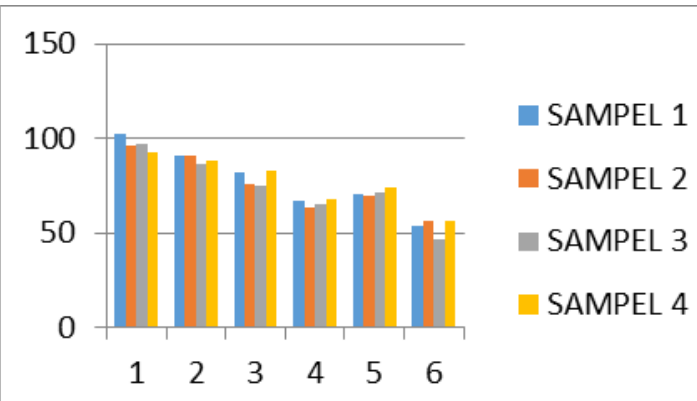

Gambar 1. Histogram nilai uji kekerasan komposit nanofiller

Data hasil penelitian kemudian ditabulasi, dan diuji distribusi normalitasnya dengan uji Saphiro-Wilk. Hasil yang didapatkan $p>0,05$ artinya data tersebut terdistribusi normal. Uji selanjutnya adalah uji homogenitas menggunakan uji Levene, dari uji ini diperoleh $p>0,05$ artinya bahwa data tersebut adalah homogen. Data diketahui berdistribusi normal dan homogen, maka analisis data dilanjutkan dengan uji parametrik One Way Anova. Hasil uji One Way Anova menunjukkan terdapat perbedaan yang signifikan antar kelompok dengan nilai signifikansi sebesar $p<0,05$. Uji selanjutnya untuk mengetahui letak perbedaan bermakna pada masing-masing kelompok, maka analisis dilanjutkan dengan uji LSD (Least Significant Difference), dari uji ini terdapat perbedaan bermakna $(p<0,05)$ antar semua kelompok, yaitu antara kelompok 1 dengan 2, 1 dengan 3, 1 dengan 4, 2 dengan 5, dan antara 2 dengan 6 .

\section{Pembahasan}

Hasil penelitian yang didapatkan menunjukkan terjadi perbedaan kekerasan yang signifikan pada kelompok resin komposit dengan olesan gliserin dan tanpa perendaman dengan kelompok tanpa olesan gliserin dan tanpa perendaman yaitu sebesar 0,03 . Selisih diantara kelompok tersebut adalah 7,83 VHN. Pada resin komposit yang mengalami polimerisasi berantai, polimerisasi diawali dengan induksi oleh radikal bebas. Pada tahap ini resin komposit terekspos di udara luar. $\mathrm{O}_{2}$ yang ada di udara dapat menurunkan excitability dari fotoinisiator dan menurunkan stabilisasi radikal bebas dengan membentuk lapisan Oxygen Inhibition Layer (OIL). OIL melapisi permukaan resin komposit dan berikatan dengan radikal bebas yang seharusya memulai tahap propagasi. Akibat dari hal ini, pembentukan polimer berkurang atau tidak dapat berlangsung sempurna. Gangguan 
pada polimerisasi dapat menyebabkan penurunan nilai kekerasan resin komposit nanofiller [7].

Pada hasil penelitian didapatkan selisih perubahan kekerasan antar sampel pada tiap kelompok tidak sama, yaitu selisih pada sampel 1 dan 2 dengan sampel 1 dan 4 kelompok resin komposit dengan aplikasi gliserin dan tanpa perendaman. Selisih kekerasan sampel 1 dengan 2 adalah 5,77 , sedangkan selisih antara sampel 1 dengan 4 adalah 9,54. Perbedaan nilai kekerasan yang besar ini kemungkinan dapat terjadi karena pada saat dilakukan indentasi, jarak antar tiga titik indentasi tiap sampel tidak sama. Kemungkinan lain yang mempengaruhi perbedaan nilai kekerasan adalah pengaplikasian gliserin pada permukaan resin komposit yang tidak merata dan volume gliserin yang tidak homogen. Volume gliserin yang tidak homogen akan menyebabkan permukaan resin komposit terekspos oleh oksigen sehingga menyebabkan hasil indentasi pada titik ini lebih rendah dari titik pada area lain.

Kekerasan resin komposit nanofiller selain dapat dipengaruhi oleh aplikasi gliserin juga dapat dipengaruhi oleh jarak penyinaan, proses polimerisasi dan ketebalan dari resin komposit nanofiller. Perpaduan antara jarak penyinaran yang tidak benar-benar menempel, ketebalan resin komposit nanofiller yang lebih dari $2 \mathrm{~mm}$, adanya sisa monomer pada proses polimerisasi yang tidak sempurna dan tidak meratanya pengaplikasian gliserin pada permukaan resin komposit nanofiller dapat menyebabkan penurunan kekerasan resin komposit nanofiller [8].

Hasil Pengukuran pH keasaman larutan cuka apel sebelum pelarutan cuka apel dalam air adalah 3,1, sedangkan setelah dilarutkan dalam air $\mathrm{pH}$ berubah menjadi 3,4. Perubahan terjadi karena konsentrasi cuka apel yang bersifat asam berkurang dalam air pelarut sehingga menyebabkan $\mathrm{pH}$ mengalami kenaikan. Nilai kekerasan resin komposit pada kelompok tanpa perendaman lebih tinggi daripada kelompok perendaman. Selisih antara kelompok gliserin tanpa perendaman dengan kelompok gliserin perendaman 60 menit adalah 17,87 VHN dengan signifikansi 0,000 dan selisih antara kelompok gliserin tanpa perendaman dengan kelompok gliserin perendaman 120 menit adalah 31,22 VHN dengan signifikansi 0,000 . Selisih antara kelompok tanpa gliserin dan tanpa perendaman dengan kelompok tanpa gliserin perendaman 60 menit adalah 17,75 VHN dengan signifikansi 0,000 . Selisih antara kelompok tanpa gliserin tanpa perendaman dengan kelompok tanpa gliserin perendaman 120 menit adalah 35,97 VHN dengan signifikansi 0,000.

Perbedaan nilai kekerasan antar kelompok perendaman dengan tanpa perendaman dapat terjadi karena pada kelompok tanpa perendaman, resin komposit tidak berkontak dengan larutan cuka apel yang bersifat asam, sehingga tidak ada ion $\mathrm{H}^{+}$yang dapat mengganggu kestabilan ikatan polimer pada resin komposit. Resin komposit mrmiliki sifat hidrofilik sehingga dapat mengabsorbsi cuka apel. Cuka apel yang asam diserap dan menyebabkan rusaknya ikatan matriks dan filler. Terganggunya ikatan ini mengakibatkan terbentuknya monomer sisa metil metakrilat. Monomer sisa akan lepas dari resin komposit, hal ini dapat menyebabkan terbentuknya microcracks dan microvoids yang terletak diantara filler dan matriks resin. Semakin lama perendaman resin komposit dalam larutan cuka apel, maka ikatan polimer pada resin komposit semakin banyak yang terputus. Semakin banyak microcracks dan microvoids yang terbentuk menyebabkan semakin besar pula zat yang dapat berpenetrasi [15].

Resin komposit dapat mengalami penurunan kekerasan melalui dua mekanisme. Mekanisme pertama yaitu molekul air yang terserap akan berdifusi ke rantai polimer dan mengisi ruang kosong antar polimer, polimer selanjutnya akan mengembang dan melunak sehingga akan menyebabkan terlepasnya monomer. Mekanisme kedua yaitu molekul air mendegradasi ikatan siloksan yaitu ikatan gugus silanol pada permukaan silika dan silane coupling agent melalui reaksi hidrolisis, hal ini akan menyebabkan ikatan antara filler dengan matriks menjadi tidak stabil dan terjadi pelepasan ion - ion partikel filler [14].

Pada hasil penelitian ini dapat dilihat kelompok perendaman 60 menit dan 120 menit memiliki perbedaan nilai kekerasan yang signifikan sebesar 0.000 pada kelompok gliserin dan 0,002 pada kelompok tanpa gliserin. Selisih nilai kekerasan antara kelompok gliserin dengan waktu perendaman 60 menit dengan waktu 120 menit adalah 13,35 VHN, sedangkan selisih nilai kekerasan antara kelompok tanpa gliserin dengan waktu perendaman 60 menit dengan waktu 120 menit adalah 18,22 VHN. Nilai kekerasan resin komposit pada kelompok perendaman 60 menit lebih tinggi dibanding kelompok perendaman 120 menit, sehingga dapat disimpulkan variabel waktu perendaman 
memiliki pengaruh terhadap kekerasan resin komposit. Resin komposit mengalami penurunan kekerasan dari waktu ke waktu hingga mencapai titik jenuhnya [8].

\section{Simpulan dan Saran}

Kesimpulan hasil penelitian ini yaitu terdapat perbedaan nilai kekerasan yang signifikan antara kelompok dengan aplikasi gliserin dan kelompok tanpa aplikasi gliserin, terdapat perbedaan nilai kekerasan yang signifikan pula pada kelompok perendaman dalam larutan cuka apel dan kelompok tanpa perendaman. Semakin lama waktu perendaman, menunjukkan perubahan kekerasan yang semakin besar, yaitu nilai kekerasan semakin menurun

Nilai kekerasan resin komposit pada kelompok 1, 2, 3, 4, 5, 6 secara berurutan adalah 96,91; 80,08; 79,04; 65,69; 71,33; 53,11. Nilai kekerasan tertinggi terdapat pada kelompok dengan aplikasi gliserin dan tanpa perendaman yaitu sebesar 96,91 VHN, sedangkan nilai kekerasan terendah terdapat pada kelompok tanpa aplikasi gliserin dan perendaman 120 menit yaitu sebesar 53,11 VHN.

Saran yang dapat diberikan yaitu perlunya pemberian informasi mengenai evaluasi periodik sehubung dengan kebiasaan mengonsumsi larutan cuka apel, perlu dilakukan penelitian lebih lanjut tentang pengaruh konsumsi cuka apel terhadap bahan restorasi lain di kedokteran gigi secara in vivo, dan kepada klinisi yang melakukan penumpatan disarankan untuk mengaplikasikan gliserin sebelum curing untuk meningkatkan kekerasan resin komposit.

\section{Daftar Pustaka}

[1] Sari, G. G. P., Nahzi M. Y. I., dan Widodo. Kebocoran mikro akibat efek suhu terhadap pengerutan komposit nanohybrid. Dentino Jurnal Kedokteran Gigi. 2016. 1(2): 108-112.

[2] Anusavice, K. J. Phillips Buku Ajar IImu Bahan Kedokteran Gigi. Terjemahan oleh Johan Arief Budiman dan Susi Purwoko. 2006. Jakarta: EGC. Halaman 237-243.

[3] Zimmerli, B., Strub F., Franziska J., Oliver S., dan Adrian. Composite materials: composition, properties and clinical applications :A literature review. 2010. 120
(11): $972-979$.

[4] Hamouda, I.M., Hagag A.E., dan Manal F.B. Microleakage of Nanofiller Composite Resin Restorative Material. Journal of Biomaterials and Nanobiotechnology. 2011. 2: 329 - 334.

[5] Putriyanti, F., Ellyza H., dan Andi, S. Pengaruh saliva buatan terhadap diametral tensile strength micro fine hybrid resin composite yang direndam dalam minuman isotonic. Jurnal PDGI. 2012. 1(1): 43-47.

[6] Yolanda, D. Aripin, dan T. Hidayat. Comparison of surface roughness of nanofill and nanohybrid composite resin polished by aluminum oxide and diamond particle paste. Padjadjaran Journal of Dentistry. 2017. 29(2):123-129.

[7] Park, H.H dan In-Bog L. 2011. Effect of glycerin on the surface hardness of composite after curing. Journal of Korean of Conservative Dentistry. 36(6): 483-489

[8] Sitanggang, P., Tambunan E., dan Wuisan J. Uji kekerasan resin komposit terhadap rendaman buah jeruk nipis (citrus aurantifolia). Journal e-GiGi (eG). 2015. 3 (1): 229-234.

[9] Kalifa, R. F., Muh D. F., dan Arlina N. Pengaruh Jus Jeruk dan Minuman Berkarbonasi terhadap kekerasan permukaan resin komposit. ODONTO dental Journal. 2017. 4(1): 38 - 43.

[10] Atro, R. A., Periadnani dan Nurmiati. Keberadaan mikroflora alami dalam fermentasi cuka apel hijau (Malus sylvestris Mill.) Cultivars Granny Smith. Jurnal Biologi Universitas Andalas. 2015. 4 (3): 158 161.

[11] Morgan, J. dan Sapha M. The potential of apple cider vinegar in the management of type 2 diabetes. International Journal of Diabetes Research. 2016.5 (6): 129-134.

[12] Adawiyah, R. Pengaruh Beda Media Pendingin pada Proses Hardening terhadap Kekerasan Baja Pegas Daun. Jurnal Poros Teknik. 2015. 7(1): 1-53.

[13] Kumayasari, M. F., dan Sultoni A. I. Studi Uji Kekerasan Rockwell Superficial VS Micro 
kharisma, et al, Pengaruh Aplikasi Glliserin pada Perendaman Cuka Apel terhadap

Vicker. Jurnal Teknologi proses dan Inovasi Industri. 2017. 2 (2): 85-89.

[14] Andari, E. S., Erawati W., dan Dwi M. C. R. 2014. Efek Larutan Kopi Robusta Terhadap Kekuatan Tekan Resin Komposit Nanofiller. Jurnal Kedokteran Gigi Unej. 11(1): 6-11.
[15] Istibsyaroh. 2015. Perubahan warna resin komposit nanofiller setelah perendaman dalam minuman susu fermentasi (penelitian in vitro). Skripsi. Jember: Fakultas Kedokteran Gigi Universitas Jember. 